\title{
KARAKTERISTIK DAN STRUKTUR MIKRO GEL CAMPURAN SEMIREFINED CARRAGEENAN DAN GLUKOMANAN
}

\section{(CHARACTERISTIC AND MICROSTRUCTURE OF MIXED GEL OF SEMIREFINED CARRAGEENAN AND GLUCOMANNAN)}

\author{
Adrianus O W Kaya ${ }^{1}$, Ani Suryani ${ }^{2}$, Joko Santoso ${ }^{3}$, dan Meika Syahbana Rusli ${ }^{2}$ \\ ${ }^{1)}$ Program Studi Teknologi Hasil Perikanan, Fakultas Perikanan dan IImu Kelautan, \\ Universitas Pattimura Ambon \\ ${ }^{2)}$ Departemen Teknologi Industri Pertanian, Fakultas Teknologi Pertanian, \\ Institut Pertanian Bogor \\ ${ }^{3)}$ Departemen Teknologi Hasil Perairan, Fakultas Perikanan dan IImu Kelautan, \\ Institut Pertanian Bogor \\ E-mail : adrianuskaya_belso@yahoo.com
}

Received : 30 September 2014; revised : 16 Oktober 2014; accepted : 20 Oktober 2014

\begin{abstract}
ABSTRAK
Karagenan dan glukomanan merupakan komponen pembentuk gel, karena memiliki pengaruh sinergis yang menghasilkan gel yang memiliki kekuatan tinggi, elastis, dan sineresis rendah. Penelitian ini bertujuan untuk mengetahui karakteristik dan struktur mikro gel kombinasi semirefined carrageenan dan glukomanan pada berbagai perbandingan. Data hasil penelitian dianalisis menggunakan rancangan acak lengkap dan dilanjutkan dengan uji Tukey. Hasil penelitian menunjukkan bahwa perbandingan campuran semirefined carrageenan dan glukomanan 1:1 memiliki nilai kekuatan gel dan kekerasan tertinggi yaitu sebesar $3.649,09 \mathrm{~g} / \mathrm{cm}^{2}$ dan $701,72 \mathrm{~g}$, perbandingan 1:3 memiliki nilai sineresis yang rendah dibandingkan dengan perbandingan lainnya yaitu sebesar $7,36 \%$, sedangkan nilai rigiditas tertinggi diperoleh perbandingan $2: 1$ yaitu sebesar $4.282,45 \mathrm{~g} / \mathrm{cm}$. Struktur mikro gel yang dihasilkan untuk semua perlakuan berbeda satu sama lainnya yaitu untuk perbandingan 1:1 memiliki struktur yang kompak dan padat. Peningkatan penambahan glukomanan akan menghasilkan gel yang lebih elastis dan cenderung lebih lembut daripada struktur matriks gel yang tidak kompak dan menggumpal serta memiliki rongga yang cukup banyak seperti ada perbandingan 1:2, 1:3, dan 1:4 sedangkan penambahan semirefined carrageenan menghasilkan gel yang keras dan kaku serta terlihat dari struktur gel yang lebih padat dan kompak dengan rongga yang terlihat pada perbandingan $2: 1,3: 1$, dan $4: 1$.
\end{abstract}

Kata kunci : Semirefined carrageenan, Glukomanan, Mikro gel

\begin{abstract}
Carrageenan and konjac glucomanan produce a gellous material with the characterisics of high gel strength, elastic texture, and low syneresis. This research was aimed to find out characteristic and structure of gel micro which combined from semirefined carrageenan and glucomannan. The data collected were analyzed using ANOVA and continued by Tukey test. The result showed that comparison ratio of 1:1 have the highest value of gel strength and hardness of $3.649,09 \mathrm{~g} / \mathrm{cm}^{2} ; 701,72 \mathrm{~g}$, comparison ratio of $1: 3$ have low syneresis is $7,36 \%$, meanwhile comparison ratio of $2: 1$ have the rigidity is $4.282,45 \mathrm{~g} / \mathrm{cm}$. Micro structure of gel which is produced from all treatment are different from each others, that the comparison ratio of 1:1 having the structure of being compact and solid. The increased of glucomannan will produce a soft gel with more ductile that shown in 1:2, $1: 3$, and 1:4, while the increased of semirefined carrageenan produce a hard, rigid, and compact gel that shown in $2: 1,3: 1$, and $4: 1$.
\end{abstract}

Keywords : Semirefined carrageenan, Glucomannan, Micro gel

\section{PENDAHULUAN}

Karagenan merupakan komponen yang diperoleh dari hasil ekstraksi rumput laut merah dengan menggunakan air panas (hot water) atau larutan alkali pada suhu tinggi $\left(85^{\circ} \mathrm{C}\right.$ sampai dengan $90{ }^{\circ} \mathrm{C}$ ) (Glicksman 1983). Imeson (2000) mengemukakan bahwa karagenan merupakan 
polisakarida berantai linier dengan berat molekul yang tinggi. Rantai polisakarida tersebut terdiri dari ikatan berulang antara gugus galaktosa dengan 3,6-anhidrogalaktosa (3,6 AG), keduanya baik yang berikatan dengan sulfat maupun tidak, dihubungkan dengan ikatan glikosidik $\alpha-(1,3)$ dan $\beta-(1,4)$. Karagenan dijual dalam bentuk bubuk, warnanya bervariasi dari putih sampai kecoklatan bergantung dari bahan mentah dan proses yang digunakan. Karagenan merupakan galaktan sulfat yang diekstrak khusus dari jenis rumput laut merah, seperti Eucheuma dan Gigartina (Bixler dan Jhondro 2006) dan biasanya diklasifikasikan ke dalam tiga kelompok utama, yaitu kappa carrageenan, iota carrageenan, dan lambda carrageenan, dengan struktur kimia yang berbeda mengakibatkan gel yang dihasilkan juga khas dalam larutan garam $\mathrm{KCl}$ (Imeson 2000). Karagenan memiliki kemampuan untuk membentuk gel secara thermo reversible sehingga banyak dimanfaatkan sebagai pembentuk gel, pengental, dan bahan penstabil di berbagai industri seperti pangan, farmasi, kosmetik, percetakan, dan tekstil (Velde et al. 2002; Campo et al. 2009). Selanjutnya dikemukakan oleh Campo et al. (2009), karagenan dikelompokkan berdasarkan strukturnya menjadi enam jenis yaitu kappa, iota, lambda, mu, nu, dan theta, keenam karagenan tersebut mempunyai sifat kimia dan fisik yang berbeda tergantung jumlah dan letak gugus sulfatnya yang bervariasi.

Karagenan memiliki kemampuan untuk membentuk gel secara thermo reversible atau larutan kental jika ditambahkan ke dalam larutan garam sehingga banyak dimanfaatkan sebagai pembentuk gel, pengental, dan bahan penstabil di berbagai industri seperti pangan, farmasi, kosmetik, percetakan, dan tekstil (Velde et al. 2002; Campo et al. 2009).

Semirefined carrageenan (SRC) adalah salah satu produk karagenan dengan tingkat kemurnian lebih rendah dibandingkan refined carrageenan, karena masih mengandung gugus sulfat yang mengakibatkan kemampuan pembentuk gelnya lebih rendah dan biasanya dibuat dalam bentuk tepung atau bubuk dan chip atau kepingan (Anggadiredja et al. 2010).

Konjak glukomanan (KGM) diekstrak dari akar umbi tanaman konjak Amorphophallus konjac (Khanna and Tester 2006) dan telah digunakan secara umum dan diakui sebagai bahan makanan aman (GRAS) serta obat tradisional di China dan Jepang (Chua et al. 2010). KGM dianggap sebagai bahan makanan non kalori, karena salah satu manfaat utama sebagai serat untuk membantu proses pencernaan, yang efektif dalam pengurangan berat badan, modifikasi metabolisme mikroba usus, dan pengurangan kolesterol (Chua et al. 2010).

Konjak larut dalam air panas atau air dingin, kekentalannya tinggi dengan $\mathrm{pH}$ antara 4,0 sampai 7,0 , berfungsi sebagai bahan pembentuk gel, pengental, pengemulsi, dan penstabil. Berdasarkan sifat tersebut diharapkan konjak dapat digunakan sebagai pencampur untuk meningkatkan elastisitas karagenan (Atmaka et al. 2013).

Manfaat lain adalah untuk meningkatkan kesehatan yang secara luas digunakan dalam makanan, suplemen diet untuk perlakuan pencegahan obesitas, minuman dan farmasi, untuk pengentalan, tekstur, pembentukan gel, dan penjernihan air (Chua et al. 2010; Keithley and Swanson 2005; Vasques et al. 2008).

Glukomanan memiliki sifat yang dapat menurunkan tegangan permukaan gel campuran kappa karagenan dan glukomanan sehingga terbentuk gel yang lebih elastis dan menurunkan sifat kerapuhan gel karagenan sehingga gel lebih kuat. Campuran karagenan dan konjak dapat menghasilkan gel yang baik karena terdapat hubungan yang sinergis dalam proses pembentukan gel sehingga dapat menghasilkan gel dengan kekuatan gel yang tinggi dan tekstur yang baik serta elastis (Imeson 2000; Penroj et al. 2005; Verawaty 2008; Yu et al. 2011).

Johnson (2007) yang diacu dari Widjanarko (2008) mengatakan bahwa sebagai bahan pembentuk gel, konjak memiliki kemampuan yang unik untuk membentuk gel reversible, dan gel irreversible pada kondisi yang berbeda. Larutan konjak tidak akan membentuk gel karena gugus asetilnya mencegah rantai panjang glukomanan untuk saling bertemu satu sama lain. Akan tetapi, konjak dapat membentuk gel dengan pemanasan sampai $85{ }^{\circ} \mathrm{C}$ dengan kondisi basa ( $\mathrm{pH} 9$ sampai dengan $\mathrm{pH} 10$ ). Gel ini bersifat tahan panas (irreversible) dan tetap stabil dengan pemanasan ulang pada suhu $100{ }^{\circ} \mathrm{C}$ atau bahkan pada suhu $200{ }^{\circ} \mathrm{C}$. Selanjutnya dikemukakan oleh Yu et al. (2011), konjak dan karagenan akan melarut dan membentuk gel dengan baik pada suhu $80^{\circ} \mathrm{C}$.

Aplikasi penggunaan semirefined carrageenan (SRC) yang dikombinasikan dengan glukomanan dalam pembuatan gel masih terbatas dan sangat diperlukan untuk mendapatkan data yang lengkap tentang karakteristik dan struktur mikro gel. Hal tersebut sangat penting dalam pemanfaatan gel campuran semirefined carrageenan dan glukomanan baik dalam bidang pangan maupun non pangan berdasarkan karateristik dan 
struktur mikro yang dihasilkan. Tujuan penelitian ini adalah untuk mengetahui karakteristik dan struktur mikro gel hasil kombinasi semirefined carrageenan dan glukomanan.

\section{BAHAN DAN METODE}

\section{Bahan}

Bahan yang digunakan dalam penelitian ini terdiri atas semirefined carrageenan (SRC) (diperoleh dari PT Ocean Fresh, Bandung, Jawa Barat), glukomanan (diperoleh dari PT Cottonii Sejahtera, Makasar, Sulawesi Selatan), dan akuades.

Alat yang digunakan terdiri atas texture analyzer merek STEVENS-LFRA, Scanning Electron Microscopy (SEM) tipe Jeol, JSM-5310LV Japan, kompor listrik, termometer air raksa, pengaduk gelas, sudip, gelas kimia, cetakan plastik, dan timbangan analitik.

\section{Metode}

Metode pembuatan gel campuran semirefined carrageenan dan glukomanan adalah metode eksperimen. Pembuatan gel campuran semirefined carrageenan dan glukomanan ( $S R C$ : glukomanan) dengan variasi campuran sebagai berikut $1: 1 ; 1: 2 ; 1: 3 ; 1: 4 ; 2: 1$; $3: 1$; dan 4:1. Penentuan formulasi pembuatan gel campuran semirefined carrageenan dan glukomanan berdasarkan pada hasil penelitian Kriatsakriangkrai and Pongsawatmanit (2005), Penroj et al. (2005), dan Verawaty (2005). TaHApan selanjutnya adalah gel hasil campuran semirefined carrageenan dan glukomanan yang dihasilkan dianalisis beberapa parameter untuk mengetahui karakteristik gel yang dihasilkan. Adapun parameter yang dianalisis terdiri dari kekuatan gel, rigidity, kekerasan, syneresis, dan struktur mikro gel.

Proses selanjutnya adalah pembuatan gel campuran semirefined carrageenan dan glukomanan yang dimulai dengan pemanasan akuades dalam gelas kimia pada suhu kurang lebih $80{ }^{\circ} \mathrm{C}$ sampai dengan $85^{\circ} \mathrm{C}$ kemudian semirefined carrageenan dan glukomanan yang telah dicampur sampai homogen dimasukkan sedikit demi sedikit ke dalam gelas kimia yang berisi akuades yang telah dipanaskan kemudian diaduk selama kurang lebih 5 menit sampai terbentuk gel, kemudian gel yang terbentuk dituang ke dalam cetakan plastik dan dibiarkan pada suhu ruang selama kurang lebih 2 jam sampai gel yang dicetak berbentuk sesuai cetakan. Adapun prosedur pembuatan gel campuran semirefined carrageenan dan glukomanan seperti terlihat pada Gambar 1.
Kekuatan, Kekerasan, Dan Rigidity Gel (Demars dan Ziegler 2001)

Metode analisis karakteristik gel campuran semirefined carrageenan dan glukomanan yang dihasilkan adalah sebagai berikut kekuatan gel, kekerasan gel, dan rigidity gel (Demars and Ziegler 2001). Analisis dilakukan dengan menggunakan texture analyzer. Jarum penusuk memiliki ukuran luas $0,1923 \mathrm{~cm}^{2}$ pada kecepatan $0,5 \mathrm{~mm} /$ detik sampai kedalaman $20 \mathrm{~mm}$, apabila posisi jarum penusuk telah berada di tengah permukaan gel, alat texture analyzer diaktifkan sampai jarum menembus permukaan gel. Evaluasi hasil pengukuran dilakukan dengan membaca grafik yang dihasilkan. Persamaan kekuatan kekerasan, dan rigidity gel adalah sebagai berikut :

Kekuatan gel $=\frac{\text { Puncak gaya }(\mathrm{g})}{\text { Luas kontak area }(\mathrm{cm} 2)}$

Kekerasan gel $=\frac{\text { Nilai peak tertinggi }(\mathrm{cm})}{\text { Nilai } \text { kalibrasi }\left(\frac{\mathrm{g}}{\mathrm{cm}}\right)}$

Rigiditas gel $=\frac{\text { Nilai kekuatan gel }(\mathrm{g} / \mathrm{cm} 2)}{\text { Setengah lebar } \operatorname{kurva}(\mathrm{cm})}$

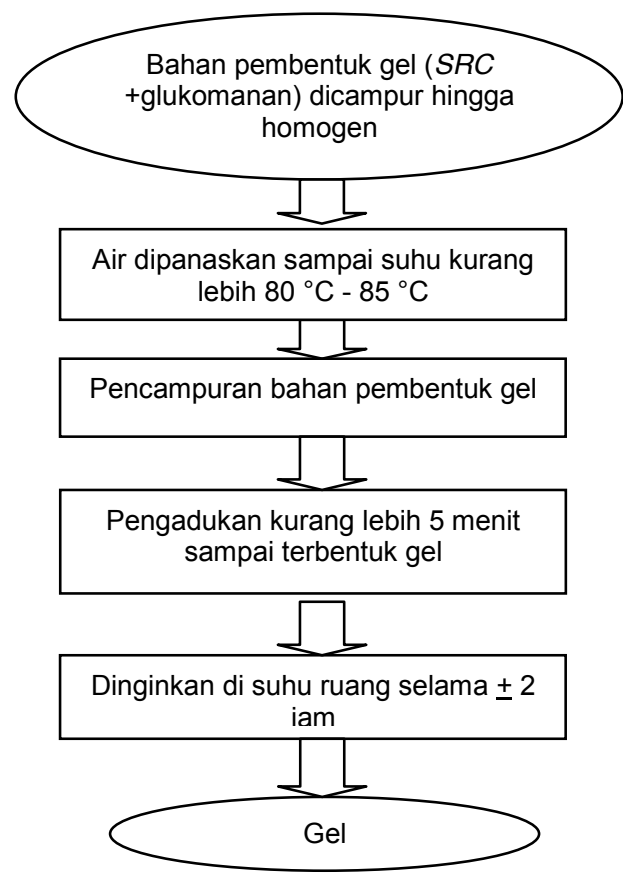

Gambar 1. Prosedur pembuatan gel campuran semirefined carrageenan dan glukomanan 
Matriks Gel (Yuliani et al. 2007)

Analisis matriks gel menggunakan SEM (Scanning Electron Microscopy). Sampel (gel) dipotong sebesar $2 \mathrm{~mm}$ sampai dengan $3 \mathrm{~mm}$ bagian sisi dalamnya kemudian dipreparasi (mendapatkan sampel dalam bentuk kering), kemudian ditempatkan di atas stubs (dudukan sampel), lalu dilapisi dengan emas menggunakan alat gold sputter coater selama 30 menit dengan ketebalan pelapisan sebesar $400{ }^{\circ} \mathrm{A}$ sampai dengan $500{ }^{\circ} \mathrm{A}$. Sampel yang telah dilapisi ditempatkan ke dalam mikroskop SEM lalu diamati pada voltase akselerasi $20 \mathrm{kV}$. Gambar yang diperoleh direkam dan dicetak. Gambar yang dihasilkan selanjutnya diukur diameter rongga atau pori dari setiap matriks gel.

\section{Syneresis (AOAC 1995)}

Syneresis yang terjadi selama penyimpanan diamati dengan menyimpan gel pada suhu ruang selama 24 jam. Syneresis dihitung dengan mengukur kehilangan bobot selama penyimpanan lalu dibandingkan dengan berat awal gel. Syneresis dinyatakan dengan rumus :

Syneresis $(\%)=\frac{\text { Bobot awal-Bobot akhir }}{\text { Bobot awal }} 100 \%$

\section{Rancangan Percobaan Dan Analisis Data}

Rancangan percobaan yang digunakan untuk menganalisis data hasil penelitian menggunakan rancangan acak lengkap satu faktor yaitu perbandingan bahan pembentuk gel dengan ulangan 3 kali (Steel and Torrie 1993). Apabila hasil analisis menunjukkan adanya pengaruh nyata, maka dilanjutkan dengan uji Tukey yang bertujuan untuk mengetahui perlakuan mana saja yang memberikan pengaruh yang berbeda nyata terhadap parameter yang diukur atau dianalisis.

\section{HASIL DAN PEMBAHASAN}

\section{Kekuatan Gel}

Kekuatan gel merupakan kemampuan gel dalam menahan beban per satuan luas. Hasil analisis kekuatan gel pada berbagai perbandingan campuran bahan pembentuk gel dapat dilihat pada Gambar 2. Hasil analisis kekuatan gel akibat perlakuan variasi perbandingan bahan pembentuk gel berkisar antara $1508,6 \quad \mathrm{~g} / \mathrm{cm}^{2}$ sampai dengan $3649,09 \mathrm{~g} / \mathrm{cm}^{2}$. Hasil analisis ragam menunjukkan bahwa perlakuan variasi perbandingan bahan pembentuk gel berpengaruh nyata terhadap kekuatan gel.

Hasil uji lanjut dengan menggunakan uji Tukey menunjukkan bahwa perlakuan variasi perbandingan bahan pembentuk gel berbeda satu dengan lainnya terhadap nilai kekuatan gel.

Peningkatan nilai kekuatan gel terjadi akibat adanya efek sinergis antara semirefined carrageenan dan glukomanan yang menghasilkan gel dengan kekuatan gel yang tinggi dan syneresis yang rendah. Peningkatan proporsi glukomanan dalam pembuatan gel mengakibatkan kekuatan gel semakin kecil atau menurun. Hal tersebut disebabkan karena glukomanan memiliki kemampuan menyerap air yang sangat besar mengakibatkan jumlah air bebas yang ada dalam gel meningkat karena syneresis yang terjadi rendah atau kecil. Kondisi tersebut menyebabkan gel mengandung air yang cukup besar menyebabkan tekstur gel yang dimiliki gel juga lebih lunak. Gel dengan tektur yang lunak akan mempunyai kemampuan menahan beban lebih kecil sehingga kekuatan gel yang dimiliki juga rendah.

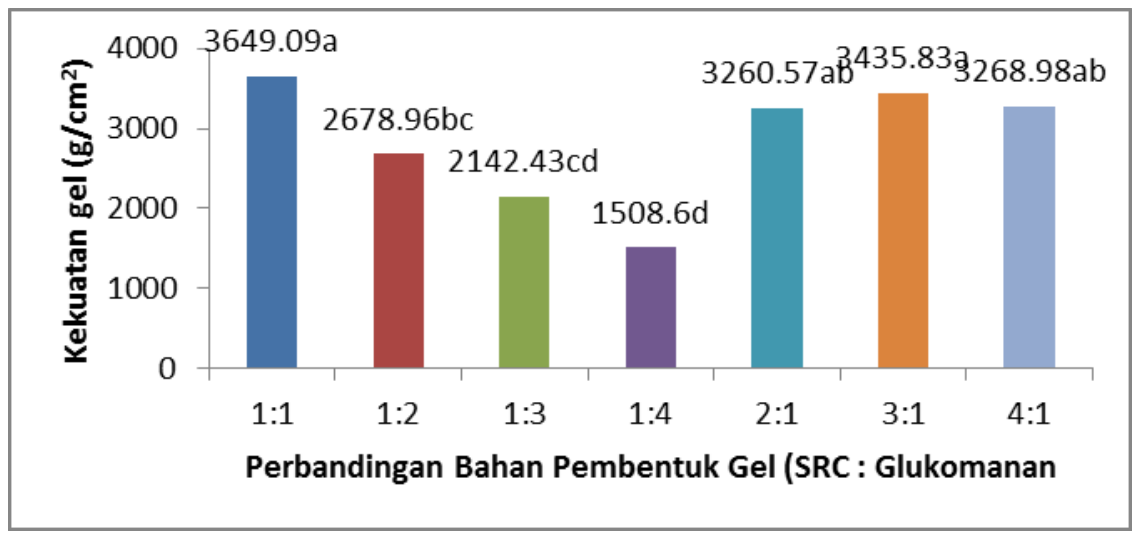

Gambar 2. Pengaruh perbandingan campuran bahan pembentuk gel terhadap kekuatan gel 
Peningkatan kekuatan gel karena terjadi efek sinergis antara glukomanan dan karagenan, sedangkan penurunan kekuatan gel karena adanya kekakuan dalam rantai seperti jumlah tipe dan posisi gugus sulfat mempunyai pengaruh yang sangat penting dalam pembentukan gel, karena akan menghambat pembentukan dan pengumpulan double helix yang selanjutnya menurunkan kekuatan gel (Glicksman 1983). Dikemukakan oleh Akesowan (2002), meningkatnya nilai gel strength disebabkan glukomanan yang teradsorbsi pada permukaan junction zone (zona ikatan) karagenan yang teragregasi, sehingga menyebabkan terjadinya penggabungan karagenan dan glukomanan. Penambahan glukomanan dalam gel agar maupun kappa karagenan berguna untuk meningkatkan kekuatan dan elastisitas gel (Tako and Nakamura 1988; Goycoolea et al. 1995).

\section{Kekerasan}

Hasil analisis kekerasan gel akibat perlakuan variasi perbandingan bahan pembentuk gel berkisar antara 291,77 gf sampai dengan 701,71 gf. Hasil analisis kekerasan gel pada berbagai perbandingan campuran bahan pembentuk gel dapat dilihat pada Gambar 3 . Hasil analisis ragam menunjukkan bahwa perlakuan variasi perbandingan bahan pembentuk gel berpengaruh nyata terhadap kekerasan gel. Hasil uji lanjut dengan menggunakan uji Tukey menunjukkan bahwa perlakuan variasi perbandingan bahan pembentuk gel berbeda satu dengan lainnya terhadap nilai kekerasan gel.

Kekerasan gel meningkat sejalan dengan meningkatnya nilai kekuatan gel. Gel yang dihasilkan oleh kappa karagenan dicirikan oleh gel dengan tekstur yang keras dan rigit. Tingginya nilai kekerasan gel disebabkan karena peningkatan penambahan jumlah semirefined carrageenan yang mengakibatkan terjadinya peningkatan jumlah agregat yang terbentuk karena adanya pembentukan pilinan ganda atau double helix. Semakin banyak pilinan ganda atau double helix yang terbentuk, maka ikatan silang antara pilinan ganda atau double helix akan menghasilkan agregat dalam jumlah banyak yaitu berupa jala-jala yang sangat kuat sehingga mengakibatkan ruang antar molekul menjadi kecil dan air bebas yang ada dalam gel terdorong keluar membuat struktur gel berubah menjadi semakin keras. Di sisi lain peningkatan proporsi glukomanan akan mengakibatkan kekerasan gel semakin menurun karena tekstur gel semakin lunak atau lembek. Glukomanan mempunyai kemampuan menyerap air yang sangat besar mengakibatkan jumlah air bebas yang ada dalam gel juga meningkat. Kondisi tersebut menyebabkan gel mengandung air yang cukup besar, sehingga tekstur gel yang dimiliki lebih lunak.

Lee et al. (2008) menyatakan bahwa jumlah zona ikatan atau junction zone dapat menjadi satu alasan tingginya tingkat syneresis. Jumlah zona ikatan yang lebih banyak dapat menyebabkan peningkatan syneresis. Hal ini disebabkan pembentukan double helix dan pembentukan agregat yang terus terjadi selama penyimpanan sehingga ikatan rantai gel semakin banyak dan rapat, sedangkan rongga antar ikatan menjadi semakin sempit yang mengakibatkan air yang tidak terikat terdorong ke luar.

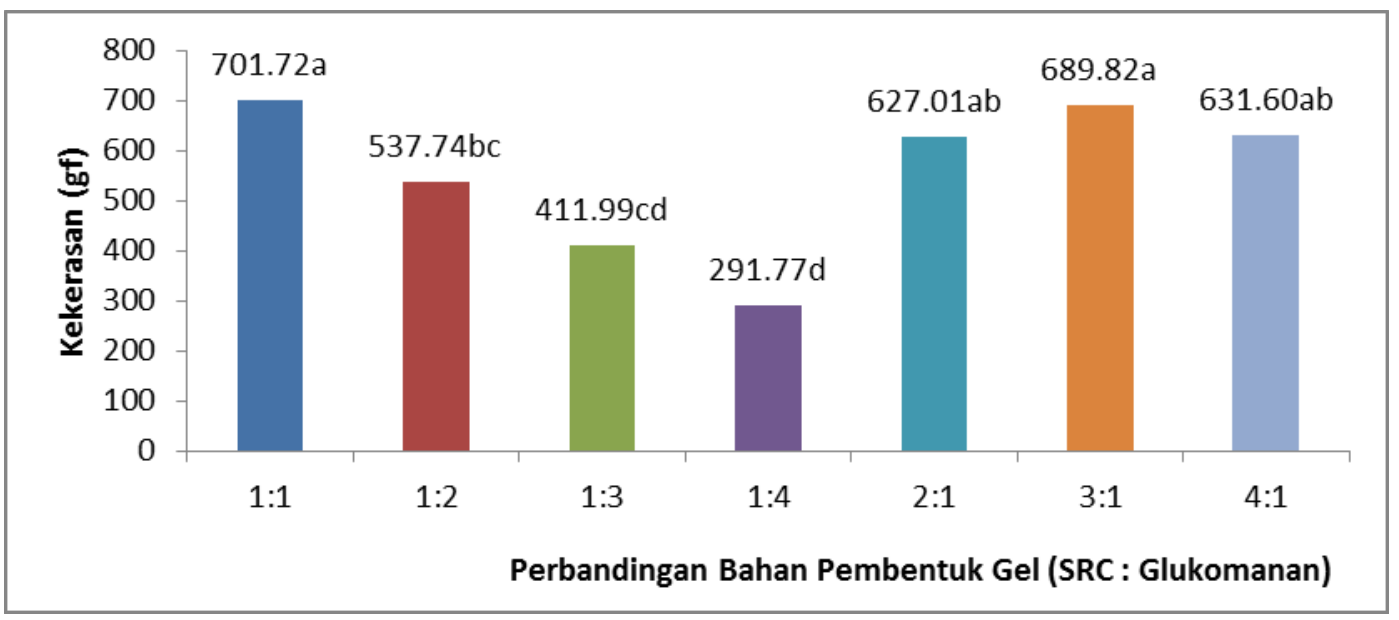

Gambar 3. Pengaruh perbandingan campuran bahan pembentuk gel terhadap kekerasan gel 
Zhou et al. (2013) mengemukakan bahwa penambahan glukomanan akan mempengaruhi sifat tekstur dari bahan seperti kekerasan dan kekenyalan. Glicksman (1983) menyatakan bahwa pembentukan agregat yang terus berlanjut selama penyimpanan dapat menjadi penyebab terjadinya syneresis. Pembentukan agregrat ini menyebabkan gel menjadi mengkerut (shrinked) sehingga cenderung memeras air keluar dari dalam gel.

\section{Rigidity}

Hasil analisis rigidity gel akibat perlakuan variasi perbandingan bahan pembentuk gel dengan berbagai variasi berkisar antara $1271,9 \mathrm{~g} / \mathrm{cm}$ sampai dengan 4282,45 $\mathrm{g} / \mathrm{cm}$. Hasil analisis rigidity gel pada berbagai perbandingan campuran bahan pembentuk gel dapat dilihat pada Gambar 4. Hasil analisis ragam menunjukkan bahwa perlakuan variasi perbandingan bahan pembentuk gel berpengaruh nyata terhadap rigidity gel. Hasil uji lanjut dengan menggunakan uji Tukey menunjukkan bahwa perlakuan variasi perbandingan bahan pembentuk gel berbeda antara satu dengan lainnya terhadap nilai rigidity gel.

Rigidity merujuk kepada elastisitas suatu produk, dengan semakin tinggi nilai rigidity maka produk yang dihasilkan semakin tidak elastis atau kaku, demikian pula sebaliknya. Setiap perbandingan bahan pembentuk gel memiliki kekuatan gel dan syneresis yang saling berbeda, kedua faktor tersebut turut mempengaruhi kestabilan gel dalam mempertahankan penguapan zat cair sehingga turut mempengaruhi elastisitas atau kekakuan gel.
Gel yang dihasilkan oleh kappa karagenan dicirikan oleh gel dengan tekstur yang keras dan rigid. Tingginya nilai rigidity gel disebabkan karena peningkatan penambahan proporsi semirefined carrageenan sehingga mengakibatkan peningkatan kekakuan gel. Kondisi tersebut disebabkan karena jumlah agregat yang terbentuk berupa jala-jala yang memiliki ikatan yang sangat kuat mengakibatkan tekstur gel menjadi keras dan rigid. Hal tersebut mengakibatkan elastisitas gel semakin rendah karena gel semakin mengkerut dan mudah pecah atau hancur.

Molekul glukomanan mempunyai kemampuan menyerap air yang sangat besar mengakibatkan jumlah air bebas yang terkandung dalam gel juga meningkat. Kondisi tersebut menyebabkan tekstur gel menjadi lebih lunak.

Peningkatan jumlah glukomanan akan mengakibatkan elastisitas gel juga meningkat karena kemampuan glukomanan dalam menurunkan tegangan permukaan dari molekul semirefined carrageenan, hal tersebut didukung oleh pernyataan Zhou et al. (2013) mengemukakan bahwa penambahan glukomanan akan mempengaruhi sifat tekstur dari bahan seperti kekerasan dan kekenyalan. Fungsi glukomanan yang mirip dengan serat mengakibatkan air terserap ke dalam molekul glukomanan sehingga meningkatkan kemampuan glukomanan dalam mengikat air (Chua et al. 2010; Takigami 2000). Berdasarkan hal tersebut maka rigidity gel juga akan mengalami perubahan seiring dengan penambahan proporsi glukomanan dalam pembuatan gel yaitu rigidity atau kekakuan gel akan semakin berkurang.

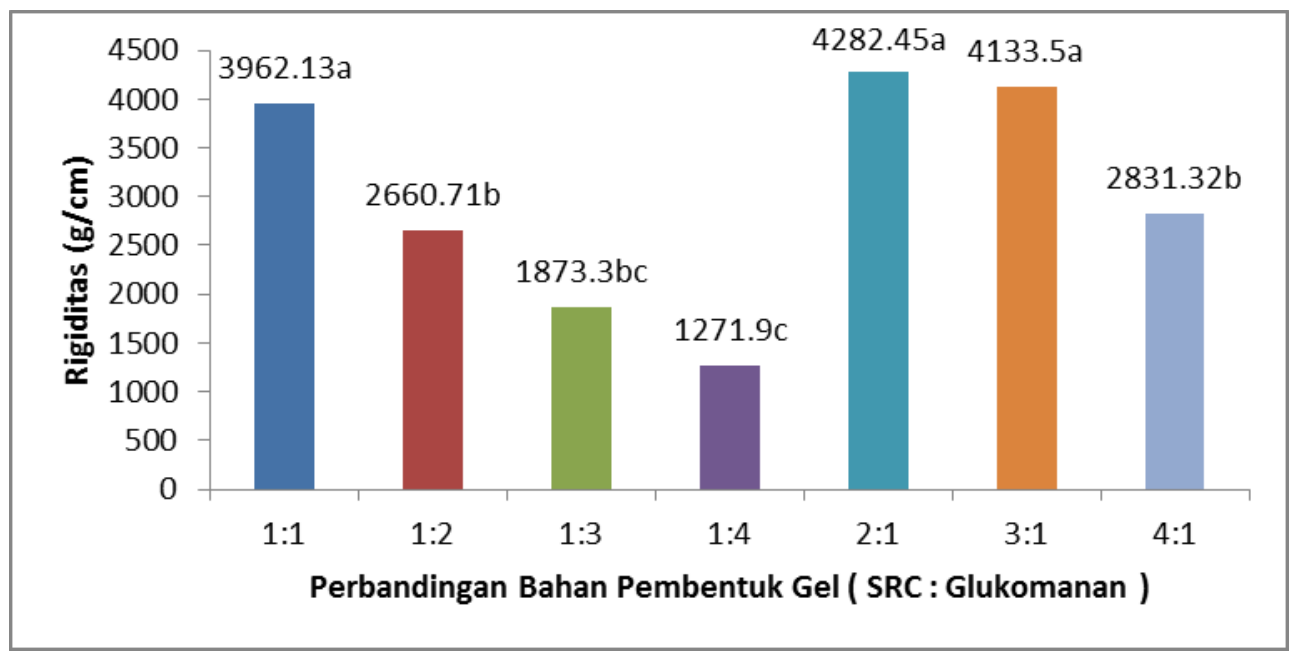

Gambar 4. Pengaruh perbandingan campuran bahan pembentuk gel terhadap rigidity gel 
Kappa karagenan memiliki tipe gel yang rigid atau mudah pecah yang dicirikan dengan tingginya syneresis yaitu adanya aliran cairan pada permukaan gel. Aliran ini berasal dari pengerutan gel sebagai akibat meningkatnya gumpalan pada daerah penghubung (Anonim 1977), selanjutnya dikemukakan bahwa kemampuan membentuk gel dari kappa karagenan terjadi pada saat larutan panas yang dibiarkan menjadi dingin, karena mengandung gugus 3,6-anhidro-D-galaktosa. Proses ini bersifat reversible. Adanya perbedaan jumlah, tipe, posisi sulfat, serta adanya ion-ion akan mempengaruhi proses pembentukan gel. Ion monovalent yaitu $\mathrm{K}, \mathrm{NH}_{4}, \mathrm{Rb}$, dan $\mathrm{Cs}$ membentuk gel. Kappa karagenen membentuk gel yang keras, kuat, dan elastis (Anonim 1977).

\section{Syneresis}

Hasil analisis syneresis gel akibat perlakuan variasi perbandingan bahan pembentuk gel berkisar antara $7,36 \%$ sampai dengan $16,35 \%$. Hasil analisis persen syneresis gel pada berbagai perbandingan campuran bahan pembentuk gel dapat dilihat pada Gambar 5.

Hasil analisis ragam menunjukkan bahwa perlakuan variasi perbandingan bahan pembentuk gel berpengaruh nyata terhadap syneresis gel. Hasil uji lanjut dengan menggunakan uji Tukey menunjukkan bahwa perlakuan variasi perbandingan bahan pembentuk gel berbeda satu dengan lainnya terhadap nilai syneresis gel.

Peningkatan jumlah semirefined carrageenan mengakibatkan terjadinya peningkatan nilai syneresis gel, hal tersebut dapat diakibatkan oleh terjadinya pembentukan pilinan ganda atau double helix dalam jumlah yang cukup banyak dan diikuti oleh terjadinya ikatan silang antara pilinan ganda atau double helix yang terbentuk menghasilkan sejumlah agregat berupa jala-jala yang saling berikatan dengan sangat kuat. Semakin banyak pilinan ganda atau double helix yang terbentuk, maka ikatan silang antara pilinan ganda yang terbentuk menghasilkan jala-jala yang semakin banyak dan saling berikatan dengan kuat mengakibatkan gel yang terbentuk semakin padat dan keras karena ruang antar molekul semakin sempit atau kecil, sehingga air bebas yang ada di dalam gel didorong atau terdesak keluar dari gel, kondisi seperti ini juga mengakibatkan gel kekurangan air dan semakin keras tekatus gel tersebut

Glukomanan mempunyai sifat yang mirip dengan serat yaitu dapat menyerap air dalam jumlah yang besar. Peningkatan proporsi glukomanan dapat menurunkan tegangan permukaan dari molekul semirefined carrageenan pada zona penghubung atau junction zone, sehingga nilai syneresis gel menjadi rendah atau kecil, kondisi tersebut disebabkan karena molekul glukomanan mampu menyerap air bebas yang ada dalam gel sehingga proses syneresis berupa keluarnya air bebas menjadi lebih kecil.

Menurut Kriatsakriangkrai and Pongsawatmanit (2005), persen syneresis tertinggi pada perbandingan glukomanan : karagenan $=0: 4$, sedangkan syneresis terendah pada proporsi $3: 1$, selanjutnya dikemukakan bahwa dengan peningkatan penambahan glukomanan akan menurunkan tingkat syneresis gel.

Syneresis tergantung pada konsentrasi kation-kation yang ada dan harus dicegah dalam jumlah yang berlebihan (Anonim 1977). Lee et al. (2008) menyatakan bahwa jumlah zona ikatan dapat menjadi satu alasan tingginya tingkat syneresis.

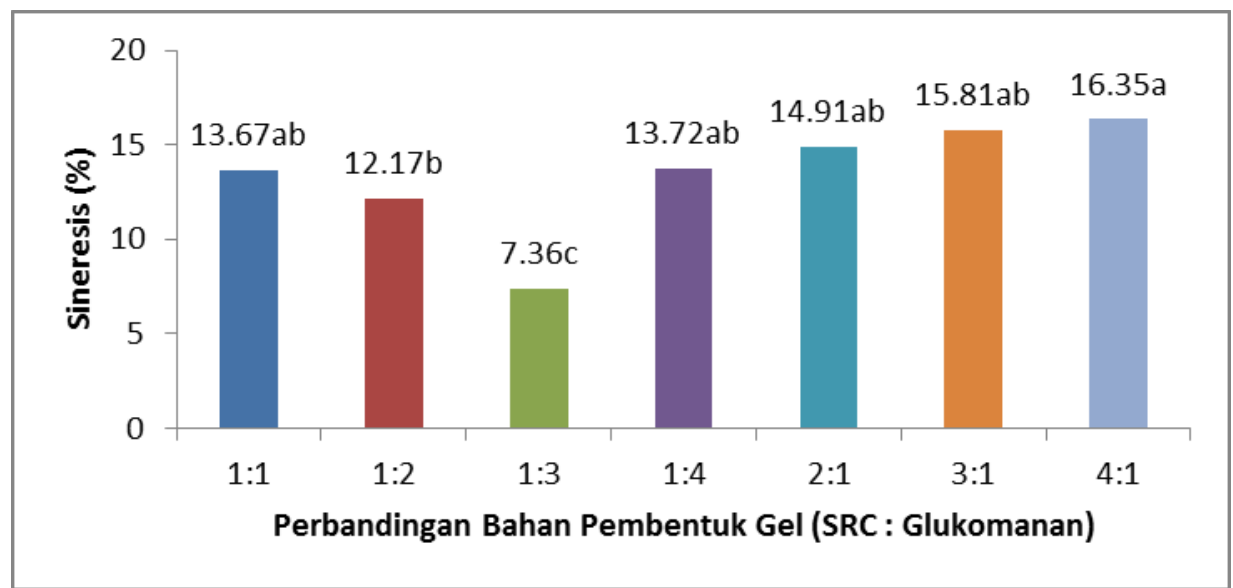

Gambar 5. Pengaruh perbandingan campuran bahan pembentuk gel terhadap persen syneresis 
Jumlah zona ikatan (junction zone) yang lebih banyak dapat menyebabkan peningkatan syneresis. Hal ini disebabkan pembentukan helix dan pembentukan agregat yang terus terjadi selama penyimpanan sehingga ikatan rantai gel semakin banyak dan rapat, sedangkan rongga antar ikatan menjadi semakin sempit yang mengakibatkan air yang tidak terikat terdorong ke luar. Glicksman (1983) menyatakan bahwa pembentukan agregat yang terus berlanjut selama penyimpanan dapat menjadi penyebab terjadinya syneresis. Pembentukan agregrat ini menyebabkan gel menjadi mengkerut (shrinked) sehingga cenderung memeras air keluar dari dalam sel. Imeson (2000) juga menyatakan bahwa diantara ketiga jenis karagenan, kappa, iota, dan lambda, hanya kappa karagenan yang akan mengalami syneresis jika berada dalam bentuk gel.

\section{Struktur Mikro Gel Glukomanan, Semirefined Carrageenan (SRC), Dan Kombinasi Antara Semirefined Carrageenan (SRC) Dengan Glukomanan}

Pengamatan struktur mikro gel yang dilakukan dengan menggunakan SEM (Scanning Electron Microscopy) bertujuan untuk mendapatkan gambaran tentang struktur mikro gel hasil kombinasi semirefined carrageenan dengan glukomanan. Hasil analisis struktur mikro glukomanan, semirefined carrageenan $(S R C)$, dan kombinasi antara SRC dan glukomanan dengan perbandingan yang bervariasi dengan menggunakan SEM (Scanning Electron Microscopy) dapat dilihat pada Gambar 6.

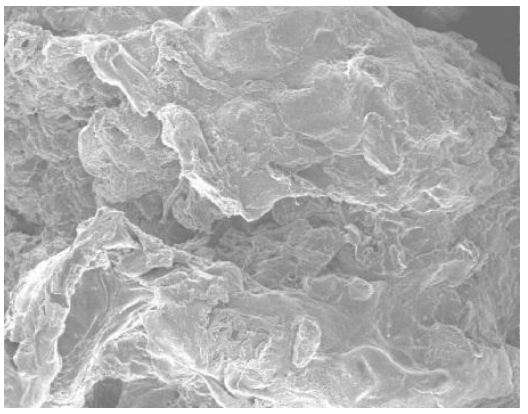

Glukomanan

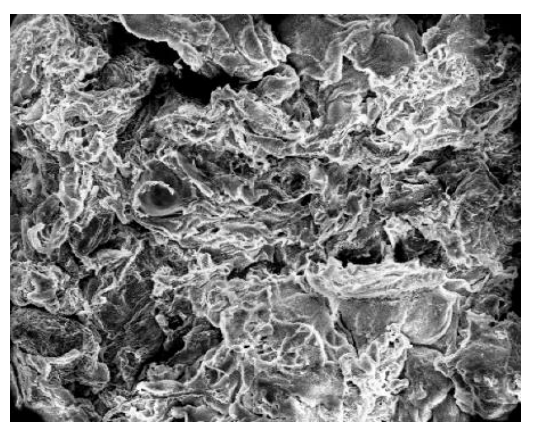

$1 S R C: 2$ Glukomannan

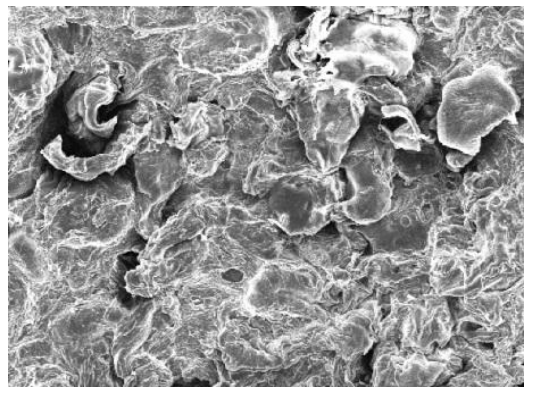

$2 S R C$ : 1 Glukomannan

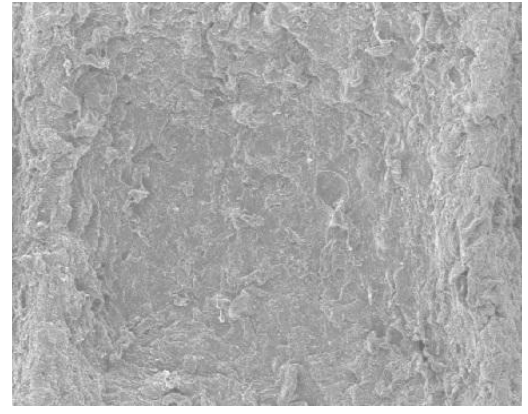

Semirefined carragenan (SRC)

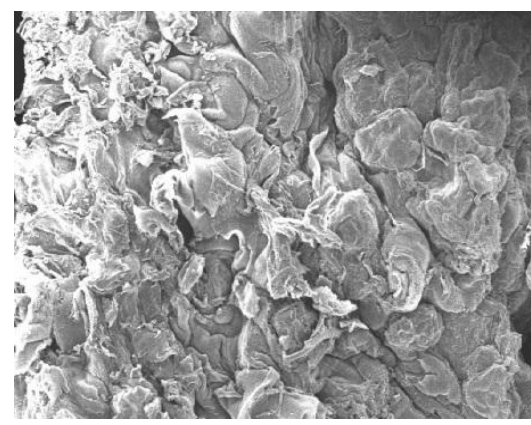

$1 S R C: 3$ Glukomannan

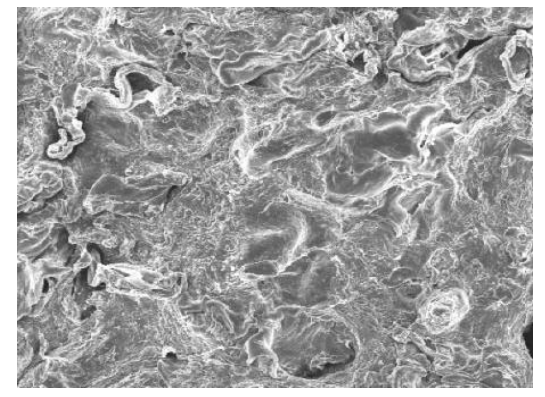

3 SRC : 1 Glukomannan

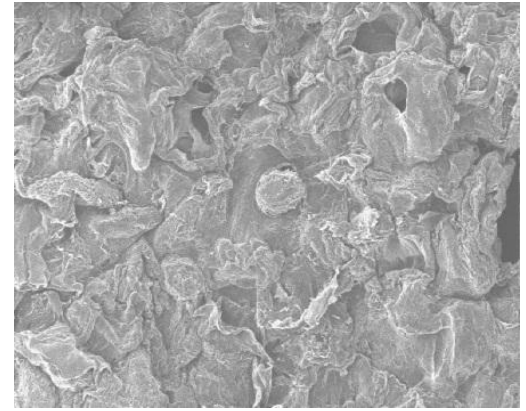

1 SRC : 1 Glukomannan

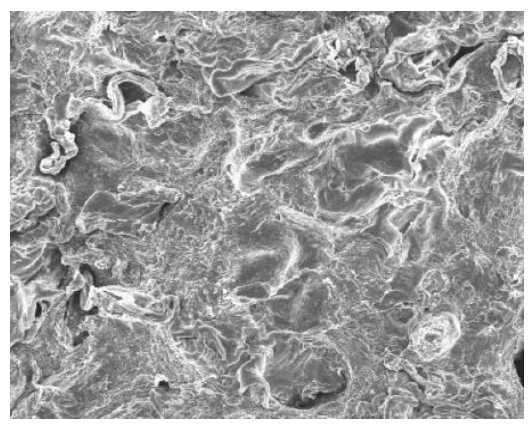

$1 S R C: 4$ Glukomannan

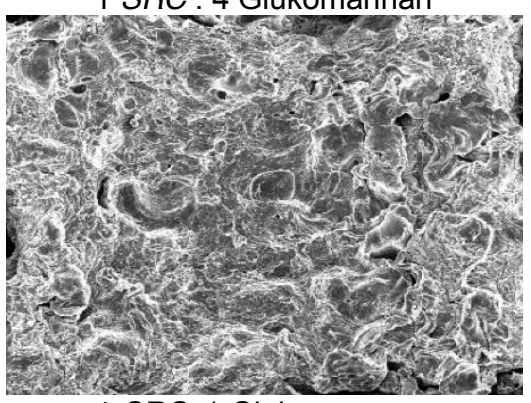

4 SRC :1 Glukomannan

Gambar 6. Struktur mikro gel glukomanan, $S R C$, dan campuran keduanya pada berbagai variasi perbandingan Keterangan gambar : TYPE JSM-5000, MAG X35, ACCV 20kV, WIDTH $3.77 \mathrm{~m}$ 
Hasil analisis struktur mikro gel kombinasi semirefined carrageenan dengan glukomanan memperlihatkan bahwa untuk perbandingan 1:1 mempunyai struktur yang kompak dan padat. Hal tersebut disebabkan karena terdapat efek sinergis yang terjadi dari proses pencampuran kedua bahan pembentuk gel tersebut. Efek sinergis tersebut terjadi karena molekul glukomanan terabsorpsi ke permukaan junction zone atau zona penghubung dari molekul semirefined carrageenan menghasilkan gel dengan kekuatan gel yang tinggi, syneresis rendah, dan tekstur gel yang padat dan kompak.

Peningkatan jumlah glukomanan akan menghasilkan gel yang lebih lembek karena fungsi glukomanan yang mirip serat sehingga mempunyai kemampuan yang lebih baik dalam mengikat air yang mengakibatkan struktur gel yang dihasilkan terlihat menggumpal karena proses syneresis berupa penguapan air bebas yang terjadi sangat kecil.

Polisakarida seperti karagenan jika dicampurkan dengan konjak, maka akan terjadi interaksi yang sinergis. Sinergisme tersebut akan menghasilkan gel dengan tekstur yang lebih elastis serta kekuatan gel yang tinggi, memperbaiki kapasitas pengikatan uap air, mengubah tekstur gel menjadi lebih elastis dan kenyal, serta memungkinkan penggunaan untuk berbagai kepentingan fungsional yang lebih besar dan tekstur untuk formulasi (BeMiller and Whistler 1996; Bubnis 2000; Chua et al. 2010; Imeson 2000; Takigami 2000; Penroj et al. 2005; Verawaty 2010; dan Yu 2011).

\section{KESIMPULAN}

Perbandingan bahan pembentuk gel 1:1 memiliki nilai kekuatan gel dan kekerasan gel tertinggi yaitu masing-masing sebesar $3.649,09 \mathrm{~g} / \mathrm{cm}^{2}$ dan $701,72 \mathrm{~g}$ serta nilai rigidity sebesar 3962,13 $\mathrm{g} / \mathrm{cm}$. Perbandingan bahan pembentuk gel 1:3 memiliki nilai syneresis yang rendah dibandingkan dengan perbandingan lainnya yaitu sebesar $7,36 \%$. Struktur mikro gel perbandingan 1:1 memiliki struktur yang kompak dan padat. Peningkatan jumlah glukomanan akan menghasilkan gel yang lebih elastis dan cenderung lebih lembut dengan struktur matriks gel yang tidak kompak dan menggumpal serta memiliki rongga yang cukup banyak, seperti pada variasi perbandingan $1: 2 ; 1: 3$; dan 1:4, sedangkan peningkatan jumlah semirefined carrageenan menghasilkan gel yang keras dan kaku dengan struktur gel yang lebih padat dan kompak dengan rongga yang sedikit, seperti terlihat pada variasi campuran perbandingan $2: 1 ; 3: 1$; dan $4: 1$

\section{DAFTAR PUSTAKA}

Akesowan, A. 2002. Viscosity and gel formation of a konjac flour from amorphophallus oncophyllus. http://www.jounal.au.edu (diakses pada tanggal 28 oktober 2014).

Anggadiredja, J.T., S. Istini, A. Zatnika, dan Suhaimi. 1986. Manfaat dan pengolahan rumput laut. Jakarta : Badan Pengkajian dan Penerapan Teknologi.

Anonim. 1977. Carrageenan. USA : Marine colloids division, FMC. Corporation.

AOAC. 1995. Official methods of analysis of the association of official analitycal chemist. DC : Washington DC, Inc.

Atmaka, W., E. Nurhartadi, dan M. M Karim. 2013. Pengaruh penggunaan campuran karagenan dan konjak terhadap karakteristik permen jelly temulawak (Curcuma xanthorrhiza Roxb.). Jurnal Teknosains Pangan 2 (2) : 66-74.

BeMiller, J. N. and R. L. Whistler. 1996. Carbohydrates in food chemistry. New York : Marcel Dekker Inc.

Bixler, H.J. and K.D. Jhondro. 2000. Philippine natural grade or semi refined carrageenan. Dalam Philips, G.O. and P. A. Williams (eds). Handbook of hydrocolloids. England : Wood head publishing : 425-441.

Bubnis, W.A. 2000. Carrageenan. http://www.fmcbiopolymer.com (diakses pada tanggal 28 oktober 2014).

Campo, V.L., D.F. Kawano, D.B.S. Junior, and I. I. Carcalho. 2009. Carrageenans: Biological Properties, Chemichal Modifiactions and structural Analysis. Carbohydrate Polymer 77 : 167-180.

Chua, M., T. C. Baldwin, T. J. Hocking, and K. Chan. 2010. Traditional uses and potential health benefits of amorphophallus konjac K. Koch ex N.E.Br. Journal of ethnopharmacology $128: 268-278$

Demars, L. L. and G. R. Ziegler. 2001. Texture and structure of gelatine/pectine based gummy confection. Food hydrocolloids 15(4-6): 643-653.

Glikcsman. 1983. Food hydrocolloids. Vol. I. Florida : CRC Press Boca Raton.

Goycoolea, F. M., R. K. Richardson, E.R. Morris, and M. J. Gidley. 1995. Effect of locust bean gum and konjac glucomannan on the conformation and rheology of 
agarose and k-carrageenan. Journal of biopolymers 36 : 643-658.

Imeson, A. P. 2000. Carrageenan. Dalam : Phillips, G. O. and P. A. Williams (eds.). Handbook of hydrocolloids. New York : CRC Press.

Katsuraya, K., K. Okuyama, K. Hatanaka, R. Oshima, T. Sato, and K. Matsuzaki. 2003. Constitution of konjac glucomannan : chemical analysis and 13C NMR spectroscopy. Carbohydrate Polymers 53 : 183-189.

Keithley, J. and B. Swanson. 2005. Glucomannan and obesity: A critical review. Alternative therapies in health and medicine $11: 30-34$.

Khanna, S. and R. Tester. 2006. Influence of purified konjac glucomannan on the gelatinisation and retrogradation properties of maize and potato starches. Food hydrocolloids 20 : 567-576.

Kritsanakriangkrai, V. and R. Pongsawatmanit. 2005. Influence of glucomannan and $\mathrm{pH}$ on properties of kappa carrageenan Gel. $31^{\text {th }}$ congress on science and technology of Thailand at Suranaree. Bangkok : University of Technology Bangkok.

Lee, J.S., Y.L. Lo, and F.Y. Chye. 2008. Effect of $\mathrm{K}^{+}, \mathrm{Ca}^{2+}$, and $\mathrm{Na}^{+}$on gelling properties of Eucheuma cottonii. Sains Malaysiana 37 (1) : 71-77.

Penroj, P., J.R. Mitchell, S.E. Hill, and W. Ganjanagunchorn. 2005. Effect of konjac glucomannan deacetylation on the properties of gels formed from mixtures of kappa carrageenan and konjac glucomannan. Carbohydrate Polymer 59 : 367 - 376.

Steel, R.D. and J.H. Torrie. 1993. Prinsip dan prosedur statistik suatu pendekatan biometrik. Jakarta : Gramedia Pustaka Utama.

Takigami, S. 2000. Konjac Mannan. Dalam : Phillips, G.O. dan P. A. Williams (eds.).
Handbook of hydrocolloids. New York : CRC Press.

Tako, M. and S. Nakamura. 1988. Synergistic interaction between agarose and $D$ galacto-D-mannan in aqueous media. Journal agriculture and biology chemistry 52 : 1071-1072.

Velde, F.V.D. and D. Ruiter GA. 2005. Carrageenan. Dalam : Polysaccharides and polyamides in the food industry. Vol 1. Weinheim : Wiley-VCH Verlag $\mathrm{GmbH}$ and Co. KGaA.

Vasques, C.A.R., S. Rossetto, G. Halmenschlager, R. Linden, E. Heckler, and M.S.P. Fernandez. 2008. Evaluation of the pharmacotherapeutic efficacy of Garcia cambogia plus Amorphophallus konjac for the treatment of obesity. Phytotheraphy Research 22 : 1135-1140. Verawaty. 2008. Pemetaan tekstur dan karakteristik gel hasil kombinasi karagenan dan konjak. Skripsi. Fakultas Teknologi Pertanian. Institut Pertanian Bogor. Bogor.

Widjanarko, S.B. 2008. Bahan pembentuk gel. http://simonbwidjanarko.files.wordpres s.com (diakses pada tanggal 28 Oktober 2014).

Yu, W., L.W. Yuan, and J.H. Xin. 2011. Gel properties of k-carrageenan and synergistic effect of k-carrageenan and konjac gum. Advanced material research $398: 1389-1393$.

Yuliani, S. dan S. Suyanti. 2007. Pengaruh laju alir umpan dan suhu inlet spray drying pada karateristik mikrokapsul oleoresin jahe. Jurnal parcapanen 4(1): 18-26.

Zhou, Y., H. Cao, M. Hou, S. Nirasawa, E. Tatsumi, T.J. Foster, and Y. Cheng. 2013. Effect of Konjac Glucomannan on physical and sensory properties of noodles made from low-protein wheat flour. Food Research Interntional 51: 879-885. 